\title{
The Perception of Using Technology Canva Application as a Media for English Teacher Creating Media Virtual Teaching and English Learning in Loei Thailand
}

\author{
Elsa Christiana \\ University Muhammadiyah Gresik, East Java, Indonesia \\ elsa_170403@umg.ac.id \\ Dr. Khoirul Anwar, S.Pd., M.Pd. \\ University Muhammadiyah Gresik, East Java, Indonesia \\ East Java, Indonesia \\ khoirulanwar@umg.ac.id
}

Received: January 10, 2021

Accepted: January 17, 2021

Published: February 31, 2021

\begin{abstract}
Online Learning requires teachers to think creatively and innovatively to attract students. Learning media becomes the main factor in helping teachers make it happen. This study aims to find out the perception of English teachers in the use of canva application as a virtual learning media creation in Loei Thailand.This research applies mixed method design that starts with collecting quantitative data. This research has proven that canva application can be used to create learning media. The result in this research was the function and benefit of canva divided into two, namely as sumplemen and subtitusi. The supplement function of canva is (1) Canva fasilitated teacher to make learning media, (2) Canva Application Improve online teaching process. The substitution function of canva is (1) Canva Application Improves learning media effectively, (2) Learning media of Canva is easy to distribute to students (3) Canva application can help the technology requirement. That is, the function of Canva obtained in this study.
\end{abstract}

Keyword: The Perception, Media, Canva Application, Virtual English Teaching and Learning

\section{Introduction}

In the 21st century, the term "technology" is an important issue in many areas including education. This is because technology has become a highway of knowledge transfer in most countries. Today's technological integration has been through innovation and transforming our society that has completely changed the way people think, work, and live (Grabe, 2007). As part of this, schools and other educational institutions that are supposed to prepare students for life in the "knowledge community" need to consider the integration of ICT in their curriculum (Ghavifekr, Afshari \&amp; Amla Salleh, 2012).

Integration of Information and Communication Technology (ICT) in education refers to the use of computerbased communication incorporated in the daily instructional process. Along with preparing students for today's digital age, teachers are seen as key players in using ICT in their daily classrooms. This is due to ICT's ability to provide a dynamic and proactive teaching and learning environment (Arnseth \& Hatlevik, 2012). Meanwhile, the purpose of ICT integration is to improve and improve the quality, accessibility, and cost efficiency of instruction delivery to students, also referring to the benefits of learning community networks to face the challenges of globalization today (Albirini, 2006, p.6). The ICT adoption process is not a single step, but it is ongoing and an ongoing step that fully supports teaching and information learning resources (Young, 2003).

The integration of ICT in education generally means a technology-based teaching and learning process that is closely related to the utilization of learning technology in schools. Due to the fact that students are familiar with technology and they will learn better in a technology-based environment, the problem of ICT integration in schools, especially in the classroom is very important. This is because, the use of technology in education contributes a lot in the pedagogical aspect in which the application of ICT will lead to effective learning with the help and support of ict

\section{2}


elements and components (Jamieson-Procter et al., 2013). It is true to say that almost all subject ranges ranging from mathematics, science, language, arts and humanists and other key fields can be learned more effectively through technology-based tools and tools. In addition, ICT provides complementary assistance and support for teachers and students where it involves effective computer-aided learning to serve the purpose of learning assistance (Jorge et al., 2003). Computers and technology do not act as substitute tools for qualified teachers but instead they are considered an additional supplement necessary for better teaching and learning. The need for ict integration in education is very important, because with the help of technology, teaching and learning not only occurs in the school environment, but can also occur even if teachers and students are physically at a distance. However, ICT integration is not a one-step learning process, but an ongoing learning process that provides a proactive teaching and learning environment (Young, 2003).

ICT can be used in a variety of ways where it helps teachers and students to learn about their respective subject areas. Technology-based teaching and learning offers a variety of interesting ways that include educational video, stimulation, data storage, database usage, mind mapping, guided discovery, brainstorming, music, the World Wide Web (www) that will make the learning process more satisfying and meaningful. On the other hand, students will benefit from ICT integration where they are not tied to a limited curriculum and resources, instead direct activities in technology-based courses designed to help them stimulate their understanding of the subject. It also helps teachers to design their lesson plans in an effective, creative, and attractive approach that will result in active student learning.

In the current situation, teachers prefer to participate in making their learning media use technology. Some researchers (Hernandez, 2017; Wiyaka, Mujiyanto, \& Rukmini, 2018) showed that technology is the most important thing in language learning media because the use of technology can increase students' motivation. They are equipped with digital age literacy, inventive thinking, high-level thinking and sound reasoning, effective communication and high productivity (Tinio, 2002). Students need them to develop their language skills. One of the controversial issues in foreign language teaching is the level of use of technology required in writing classes, including media formats.

Media formats, the physical form in which content is inserted and displayed, facilitate the learning process. Visual media is a type of media used for language learning. It can be diagrams on computer screens, whiteboard drawings, photos, book graphics, cartoons, etc. (Smaldino, Lowther, Mims, \&amp; Russell, 2015). This media provides a learning experience that is consistent with the character of the student as a digital native. Visual media also supports the creation of EFL students, expressing themselves to communicate with others.

Canva, a website graphic design tool, is a visual technology medium with a drag-and-drop format and provides access to over a million photos, graphics, and fonts. It has millions of images, photo filters, icons and free shapes, and hundreds of fonts (Canva, n.d.). Canva as a website is a source of visual media that can be used as a window into the wider world outside of language classes and, of course, a collection of authentic materials that are easily accessible.

Canva can be integrated to promote learning. Smaldino et al., (2015) states that visuals in the classroom, including Canva, can serve several purposes, such as; 1 ) to create concrete abstract ideas; 2) to motivate students; 3 ) to give direct attention; 4) to repeat the information; 5) to remember prior knowledge; and 6) to make learning effective. Canva is believed to be a tool to move in just a few clicks from abstract ideas to concrete sitemaps. In addition, it can create a positive learning environment through the facilities provided, thereby affecting students' concentration, memory, and attitudes. If students feel positive about their situation, they will also feel more positive about what they are doing and will be more willing to participate through direct attention in the learning process. Therefore, teachers are working on several ways to create technology-based learning media to achieve these learning goals. Canva provides features that teachers can use in creating learning media Smaldino et al., (2015).

Therefore, the study intends to find out the perception of English teachers in the use of canva application as a virtual learning media creation in Loei Thailand.

\section{Method}


This research applied the design of mixed methods that begin with collecting quantitative data. After analyzing quantitative data, qualitative data was then collected and analyzed. 20 teachers were asked to fill out a questionnaire to find out their perspective on the use of Canva. Researcher adapt the questioner from Smaldino, et al (2015). After getting the data, researcher use quantitative method in analyzing data. researcher used SPPS descriptive statistic. Then, qualitative method is used to obtain a perspective that is found to be a descriptive interpretation of a case (Arikunto, 2010). Qualitative methods were used to find perspectives of English teachers in response to the use of canva application as a virtual learning media creation in Loei Thailand. In this case it involved an English teacher in Loei Thailand. Data collection using interviews conducted by English teachers in Loei Thailand. The results of the questionnaire analysis by using descriptive statistic and interpretation data were then linked to related theories.

\section{Finding}

This research has obtained results about The Perception of Using Technology Canva Application as a Media for English Teacher Creating Media Virtual Teaching and English Learning in Loei Thailand. This study used questionnaires that were distributed to respondents. Questionnaires are scale 5 or likeert scale and then used using SPSS. Researchers provide twenty questions, but the results contained by researchers in this part have been grouped into 3 parts namely Knowledge about Canva Learning, Utilization of CANVA application as a supplement and Utilization of CANVA application as substitution.

1. Knowledge of Canva Learning

At this stage, researchers have obtained a perception of their knowledge of canva application and its interest in using canva application to create learning media. The researchers asked two questions with the following details:

Table 1

The knowledge about Canva

\begin{tabular}{llr|r|r|r} 
& & & & & \\
\hline Valid & Frequency & Percent & Valid Percent & Cumulative Percent \\
\cline { 2 - 6 } & 1.00 & 1 & 5.0 & 5.0 & 5.0 \\
\cline { 2 - 6 } & 2.00 & 4 & 20.0 & 20.0 & 25.0 \\
\cline { 2 - 6 } & 3.00 & 10 & 50.0 & 50.0 & 75.0 \\
\cline { 2 - 6 } & 4.00 & 4 & 20.0 & 20.0 & 95.0 \\
\cline { 2 - 6 } & 5.00 & 1 & 5.0 & 5.0 & 100.0 \\
\cline { 2 - 6 } & Total & 20 & 100.0 & 100.0 & \\
\hline
\end{tabular}

Table 2

\begin{tabular}{|c|c|c|c|c|c|}
\hline \multicolumn{6}{|c|}{ The Interest in using Canva application } \\
\hline & & Frequency & Percent & Valid Percent & $\begin{array}{c}\text { Cumulative } \\
\text { Percent }\end{array}$ \\
\hline \multirow[t]{3}{*}{ Valid } & 1.00 & 13 & 65.0 & 65.0 & 65.0 \\
\hline & 2.00 & 4 & 20.0 & 20.0 & 85.0 \\
\hline & 3.00 & 1 & 5.0 & 5.0 & 90.0 \\
\hline
\end{tabular}




\begin{tabular}{lr|r|r|r|r}
\cline { 2 - 5 } 1 shows & 4.00 & 2 & 10.0 & 10.0 & 100.0 \\
\cline { 2 - 6 } & Total & 20 & 100.0 & 100.0 & \\
\cline { 2 - 6 }
\end{tabular}

Table that respondents' knowledge of Canva is in a balanced position. Which is where the table shows that $5 \%$ of respondents stated that they did not know about canva application at all, while $20 \%$ stated that they did not know about canva application, 50\% knew enough about Canva and 20\% found out about canva, the last one at least 5\% indicated they knew very well about Canva. It can be concluded that, most respondents do not know much about the Canva application.

Table 2 shows an interest in responding to Canva's application as a learning media maker. Most of them show disinterest in using the canva application. Because as many as $65 \%$ of them expressed very uninterested in using the Canva application and only $10 \%$ expressed interest in using the Canva application. Unfortunately, the respondents have not been interested in using the Canva application because through interviews they use applications that are very easy to use such as sending pdf modules, power points and the like.

2. Utilization of CANVA application as a supplement

Utilization of canva application as a supplement is an objective to know the benefits that canva application has for respondents. Researchers provided 3 statements related to this. The statement is Canva for creating Learning Media, Canva Application is easy to understand and Canva fasilitated teacher to make learning media.

Table 3

Canva for creating Learning Media

\begin{tabular}{lrr|r|r|r} 
& & & & \multicolumn{2}{c}{$\begin{array}{c}\text { Cumulative } \\
\text { Percent }\end{array}$} \\
\hline Valid & \multicolumn{1}{c|}{ Frequency } & \multicolumn{1}{c|}{ Percent } & Valid Percent & 10.0 \\
\cline { 2 - 6 } & 2.00 & 2 & 10.0 & 10.0 & 40.0 \\
\cline { 2 - 6 } & 3.00 & 6 & 30.0 & 30.0 & 90.0 \\
\cline { 2 - 6 } & 4.00 & 50.0 & 50.0 & 100.0 \\
\cline { 2 - 6 } & 5.00 & 10 & 10.0 & 10.0 & \\
\cline { 2 - 6 } & Total & 20 & 100.0 & 100.0 & \\
\hline
\end{tabular}

Table 3 shows respondents' perception in responding that canva learning is used to create learning media. The results were pretty good because most of them agreed with the statement. A total of $50 \%$ agreed on the statement and $10 \%$ strongly agreed. While $10 \%$ expressed their disagree and $30 \%$ agreed enough about the statement. So, respondents actually know that jokes are used to create learning media.

Table 4

Canva Application is easy to understand

\begin{tabular}{rrr|r|r|r} 
& & & & \multicolumn{2}{c}{$\begin{array}{c}\text { Cumulative } \\
\text { Percent }\end{array}$} \\
\hline Valid & 1.00 & 1 & 5.0 & 5.0 & 5.0 \\
\cline { 2 - 6 } & 2.00 & 6 & 30.0 & 30.0 & 35.0 \\
\hline
\end{tabular}




\begin{tabular}{l|r|r|r|r}
\hline 3.00 & 9 & 45.0 & 45.0 & 80.0 \\
\hline 4.00 & 4 & 20.0 & 20.0 & 100.0 \\
\hline Total & 20 & 100.0 & 100.0 & \\
\hline
\end{tabular}

In a statement in table 4 researchers wanted to know the respondents' perspective on how to understand canva applications.as many as $45 \%$ and $20 \%$ of them stated that they "quite easily understand" and "have understood" the canva application. While as many as 5\% and 30\% stated that they "do not understand at all" and "do not understand" about the application canva. Therefore most of them understand how canva application.

Table 5

Canva fasilitated teacher to make learning media

\begin{tabular}{cr|r|r|r|r} 
& & & & \multicolumn{2}{c}{$\begin{array}{c}\text { Cumulative } \\
\text { Percent }\end{array}$} \\
\hline Valid & \multicolumn{1}{c|}{ Frequency } & \multicolumn{1}{c|}{ Percent } & Valid Percent & 5.0 \\
\cline { 2 - 6 } & 1.00 & 1 & 5.0 & 5.0 & 15.0 \\
\cline { 2 - 6 } & 2.00 & 2 & 10.0 & 10.0 & 50.0 \\
\cline { 2 - 6 } & 3.00 & 35.0 & 35.0 & 80.0 \\
\cline { 2 - 6 } & 4.00 & 6 & 30.0 & 30.0 & 100.0 \\
\cline { 2 - 6 } & 5.00 & 20.0 & 20.0 & \\
\cline { 2 - 6 } & Total & 20 & 100.0 & 100.0 & \\
\hline
\end{tabular}

Table 5 shows the function of canva as a facility for teachers in creating learning media. A total of $5 \%$ of respondents disagreed with the statement at all, while $10 \%$ disagreed with the statement, $25 \%$ strongly agreed with the statement and 30\% agreed with the statement, the latter $20 \%$ indicated they strongly agreed with the statement. It can be concluded that, most respondents understand the function of canva as a creator of learning media.

3. Utilization of CANVA application as substitution

Table 6

Canva Application is easy to use

\begin{tabular}{cc|c|c|c|c} 
& & & & Cumulative \\
& & Frequency & Percent & Valid Percent & Percent \\
\hline Valid & 3.00 & 9 & 45.0 & 45.0 & 45.0 \\
\cline { 2 - 6 } & 4.00 & 5 & 25.0 & 25.0 & 70.0 \\
\cline { 2 - 6 } & 5.00 & 6 & 30.0 & 30.0 & 100.0 \\
\cline { 2 - 6 } & Total & 20 & 100.0 & 100.0 & \\
\hline
\end{tabular}

Almost the same as the previous table 3 to ask for the convenience given by the canva application. Table 6 aims to find out the perspective of respondents in feeling the ease of application canva. The results of the questionnaire showed that $45 \%$ stated that canva application is quite easy to use, $25 \%$ stated that canva application is easy to use and $30 \%$ stated that canva application is very easy to use. This result concludes that the canva application is actually easy to use.

Table 7

Canva Application Improve online teaching process

\begin{tabular}{cc|c|c|c|c} 
& & & & & Cumulative \\
& & Frequency & Percent & Valid Percent & Percent \\
\hline Valid & 1.00 & 2 & 10.0 & 10.0 & 10.0 \\
\cline { 2 - 6 } & 2.00 & 2 & 10.0 & 10.0 & 20.0 \\
\cline { 2 - 6 } & 3.00 & 7 & 35.0 & 35.0 & 55.0 \\
\hline & 4.00 & 7 & 35.0 & 35.0 & 90.0 \\
\hline
\end{tabular}


Published by English Language Education Department of UMG

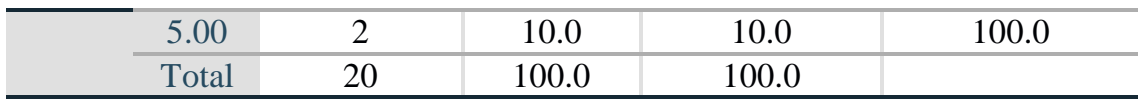

In Table 7, researchers wanted to know the perspective of rspondents on canva applications that can improve the online teaching process. Respondents replied that they stated that canva applications do not greatly improve the learning process and do not improve the learning process by $10 \%$ each. While as many as $35 \%$ answered that canva application is enough to improve the learning process, $35 \%$ stated that canva application improves the learning process and $10 \%$ think that canva application greatly improves the learning process. It can be concluded that canva application can improve the learning process.

Table 8

Canva Application Improves learning media effectively

\begin{tabular}{ccc|c|c|c} 
& & & & $\begin{array}{c}\text { Cumulative } \\
\text { Percent }\end{array}$ \\
\hline \multirow{3}{*}{ Valid } & Frequency & Percent & Valid Percent & 15.0 \\
\cline { 2 - 6 } & 3.00 & 3 & 15.0 & 15.0 & 70.0 \\
\cline { 2 - 6 } & 4.00 & 11 & 55.0 & 55.0 & 100.0 \\
\cline { 2 - 6 } & 5.00 & 6 & 30.0 & 30.0 & \\
\hline
\end{tabular}

Table 8 shows the respondent's perspective on the function of canva applications that improve learning media effectively. A total of 15\% agreed with this statement, 55\% agreed with this statement and 30\% strongly agreed with this statement. So it is concluded that cnva application can improve learning media effectively.

Table 9

Learning media of Canva is easy to distribute to students

\begin{tabular}{ccc|c|c|c} 
& & & & \multicolumn{1}{c}{$\begin{array}{c}\text { Cumulative } \\
\text { Percent }\end{array}$} \\
\hline \multirow{3}{*}{ Valid } & Frequency & Percent & Valid Percent & 25.0 \\
\cline { 2 - 6 } & 4.00 & 5 & 25.0 & 25.0 & 85.0 \\
\cline { 2 - 6 } & 4.00 & 12 & 60.0 & 60.0 & 100.0 \\
\cline { 2 - 6 } & 5.00 & 3 & 15.0 & 15.0 & \\
\cline { 2 - 6 } & Total & 20 & 100.0 & 100.0 & \\
\hline
\end{tabular}

Table 9 shows the results of learning media produced by canva easy to share with students. A total of $25 \%$ agree with this statement, $60 \%$ agree with this statement and at least $15 \%$ strongly agree with this statement. So it is concluded that the learning media produced by canva is easy to share with students.

Table 10

Canva application can help the technology requirement

\begin{tabular}{cc|c|c|c|c} 
& & Frequency & Percent & Valid Percent & $\begin{array}{c}\text { Cumulative } \\
\text { Percent }\end{array}$ \\
\hline Valid & .00 & 8 & 40.0 & 40.0 & 40.0 \\
\cline { 2 - 6 } & 1.00 & 1 & 5.0 & 5.0 & 45.0 \\
\cline { 2 - 6 } & 4.00 & 7 & 35.0 & 35.0 & 80.0 \\
\hline & 5.00 & 4 & 20.0 & 20.0 & 100.0 \\
\cline { 2 - 6 } & Total & 20 & 100.0 & 100.0 & \\
\hline
\end{tabular}

Table 10 shows results from the respondent's perspective on the function of canva applications in assisting technology needs. A total of $40 \%$ chose not to respond to this statement. 5\% disagreed, $35 \%$ agreed, and $20 \%$ strongly agreed with the statement. It can be concluded that most respondents believe that canva application can help the needs of technology in the process of teaching and learning in terms of learning media.

\section{Discussion}


Based on the results of the study, researchers found the perspective of English teachers in the use of canva application as a virtual learning media creation in Loei Thailand. Results show most of them believe that canva applications can be used as a learning medium. This is in line with a statement from Smaldino et al., (2015). Canva provides features that teachers can use in creating learning media. So this research also supports smaldino's statement that canva application is used to create learning media.

Canva can be integrated to promote learning. Smaldino et al., (2015) states that visuals in the classroom, including Canva, can serve several purposes, such as; 1 ) to create concrete abstract ideas; 2) to motivate students; 3 ) to give direct attention; 4) to repeat the information; 5) to remember prior knowledge; and 6) to make learning effective. This study obtained different results from the statement. Because the focus in research is different. This research focuses more on one function of canfa, namely as a maker of defense media while Smaldino canva statements for learning in the classroom.

The result in this research is the function and benefit of canva divided into two, namely as sumplemen and subtitusi. The supplement function of canva is (1) Canva fasilitated teacher to make learning media, (2) Canva Application Improve online teaching process. The substitution function of canva is (1) Canva Application Improves learning media effectively, (2) Learning media of Canva is easy to distribute to students (3) Canva application can help the technology requirement. That is, the function of Canva obtained in this study. Contrary to the results of this study with some theories that already are that this study found if the interest of teachers in using Canva as a learning design is in a very low percentage. The interest rate is only $10 \%$, this is due to the large number of applications that provide the same facilities and easy to use. Currently, the learning media created by teachers must be practical and not burdensome for all circles. While Canva is a high class application so that only certain people and teachers can practice it.

Infers Online Learning requires teachers to think creatively and innovatively to attract students. Learning media becomes the main factor in helping teachers make it happen. There are many tools to create technology-based learning media, one of which is the Canva application. This research has proven that canva application can be used to create learning media. The result in this research is the function and benefit of canva divided into two, namely as sumplemen and subtitusi. The supplement function of canva is (1) Canva fasilitated teacher to make learning media, (2) Canva Application Improve online teaching process. The substitution function of canva is (1) Canva Application Improves learning media effectively, (2) Learning media of Canva is easy to distribute to students (3) Canva application can help the technology requirement. That is, the function of Canva obtained in this study.

The results of canva's knowledge are very different from their interest in using it. they believe that canva applications are well used for those functions. however, they are not interested in using it. so it can be concluded that this application is very useful and helpful for some people who really master the technology. While it is difficult to reach for teachers who are lay about technology that only knows power points and the web without paying.

\section{References}

Aeni, U., Chandra, E., \& Muspiroh, N. (2016). IDENTIFIKASI KESULITAN GURU BIOLOGI DALAM MELAKSANAKAN PEMBELAJARAN KURIKULUM 2013 DI SMA NEGERI 1 SUSUKANCIREBON. Scientiae Educatia: Jurnal Sains dan Pendidikan Sains Vol. 5 (2016) No. 2: 165-174.

Albirini, A. (2006). Teachers' attitudes toward information and communication technologies: The case of Syrian EFL teachers. . Computers \& Education, 47(4).

Arnseth, H., \& Hatlevik, O. (2010). Challenges in aligning pedagogical practices and pupils' competencies with the Information Society's demands. Hershey: IGI global.

Ghavifekr, S., Afshari, M., \& Salleh, A. (2017). Management strategies for E-Learning system as the core component of systemic change: A qualitative analysis. Life Science Journal.

Grabe, M. (2007). Integrating technology for meaningful learning (5th ed.). . Boston MA: Houghton Mifflin. 
Hernandez, R. M. (2017). Impacto de las TIC en la educación: Retos y perspectivas. Propósitos y Representaciones. Jamieson-Proctor. (2013). Development of the TTF TPACK Survey Instrument. Australian Educational Computing.

Jorge, C. M. (2003). Use of the ICTs and the perception of e-learning among university students: A differential perspective according to gender and degree year group. Interactive Educational Multimedia.

Smaldino, S. E. (2015). Instructional technology and media for learning. New York: Pearson.

Tinio, V. L. (2002). Survey of information \& communication technology utilization in Philippine public high schools.

Young, S. C. (2003). Integrating ICT into second language education in a vocational high school. Journal of Computers Assisted Learning. 